\title{
Impact of Cadmium and Selenium Exposure on Trace Elements, Fatty Acids and Oxidative stress in Lepidium sativum
}

\author{
Eunice Yáñez Barrientos, Crescencio Rodríguez Flores, Kazimierz Wrobel, and Katarzyna Wrobel* \\ Departamento de Química, División de Ciencias Naturales y Exactas, Universidad de Guanajuato, Campus Guanajuato, L. de \\ Retana 5, 36000 Guanajuato, Gto., México, Tel. +52 473 7327555, katarzyn@ugto.mx
}

Dedicated to Dr. Estela Sánchez de Jiménez for her invaluable contributions to plant biochemistry

Received January 3, 2011; accepted April 1, 2011

\begin{abstract}
The objective of this work was to examine possible effects that the exposure to cadmium and selenium might have in Lepidium sativum. Nine hydroponic cultures were obtained, according to the three level factorial design that covered plants exposure to $0,0.5,2.0$ $\mathrm{mg} \mathrm{L}^{-1}$ of cadmium (as cadmium chloride) and selenium (as sodium selenite). Shoots growth was evaluated during two weeks after germination and the following parameters were measured in the biomass: $\mathrm{Cd}, \mathrm{Se}, \mathrm{Mn}, \mathrm{Zn}, \mathrm{Cu}, \mathrm{Mo}$, fatty acids and malondialdehyde. The results obtained indicate that selenium is capable to counterbalance the adverse effects of cadmium in terms of growth inhibition, decreased concentration levels of essential micronutrients and oxidative damage; however, such protective role is apparently restricted by the concentration levels of two elements in the growth medium.

Key words: Lepidium sativum, selenium, cadmium, mineral micronutrients, fatty acids, oxidative stress.
\end{abstract}

\section{Introduction}

Metallomics has emerged as a research area aimed at the understanding of global pathways and specific functions of metals and metalloids in living organisms [1]. In regard to plants, molecular mechanisms underlying elements uptake and transportation as well as plant defensive and adaptive responses are of special interest $[2,3]$. The related tasks for analytical chemistry involve quantification of elements in the growth medium and in different plant compartments, speciation analysis, assessment of element interactions with biomolecules and evaluation of possible synergic or antagonistic relations among micronutrients and non-essential xenobiotics [4]. On the other hand, the quantification of a wide variety of organic compounds, indicators of plant response to abiotic stress imposed by metals, should also be mentioned $[5,6]$. The elements of major concern in plant metallomics studies are heavy metals such as mercury, cadmium or lead and the metalloids as selenium and arsenic [4].

Selenium is an important trace element nutrient with multiple roles in higher animals and in humans. Due to sub-optimal intakes of this element in the populations of many countries, different supplementation strategies have become a common practice, including in-vivo fortification of edible vegetables [7]. In this sense, selenium accumulating plants from Allium and Brassicaceae families have been extensively studied [8-10]. On the other hand, there are numerous evidences that selenium promotes the plant growth and may act as the antagonist of heavy
Resumen. El objetivo del presente trabajo ha sido examinar posibles efectos relacionados con la exposición de Lepidium sativum a diferentes concentraciones de cadmio y selenio. Las plantas fueron cultivadas en hidroponia, en presencia de uno o dos elementos, empleando el diseño factorial de tres niveles para obtener las concentraciones 0 , $0.5,2.0 \mathrm{mg} \mathrm{L}^{-1} \mathrm{de} \mathrm{Cd}$ (como cloruro de cadmio) y Se (como selenito de sodio). Se evaluó el crecimiento de plantas durante dos semanas y en cada uno de los cultivos se determinaron los siguientes parámetros: $\mathrm{Cd}, \mathrm{Se}, \mathrm{Mn}, \mathrm{Zn}, \mathrm{Cu}$, Mo, ácidos grasos y malondialdehido. Los resultados obtenidos ponen de manifiesto que selenio tiene capacidad de reducir los efectos nocivos de cadmio en términos de la inhibición de crecimiento, decremento de las concentraciones de micronutrientes minerales y aumento de estrés oxidativo; sin embargo, el efecto global de los dos elementos depende de las concentraciones individuales de $\mathrm{Cd}$ y Se en el medio de crecimiento.

Palabras clave: Lepidium sativum, selenio, cadmio, micronutrientes minerales, ácidos grasos, estrés oxidativo.

metals [11]. In particular, its protective role in different plant species exposed to mercury, cadmium, aluminum and arsenic, has recently been addressed [11-13].

An environmental pollutant, cadmium, is readily taken from the soil by plant roots and its adverse physiological effects are well established [14]. The exposure to elevated cadmium concentrations usually leads to growth inhibition, interferences with mineral uptake, disturbance of the redox control of the cell, stimulation of secondary metabolism, alteration of membrane functions and eventually, cell death $[5,15,16]$. Nonetheless, it has recently been postulated that the response to $\mathrm{Cd}$ exposure should be associated with the systematic group of plant species and related physiological characteristics rather than with the amount of Cd taken up from the growth medium [16]. Several studies have dealt with potential protective role of selenium against cadmium toxicity in different organisms [12, 16-20]. It has been accepted that selenium tends to counterbalance Cdinduced oxidative damage, yet specific molecular mechanisms responsible for cadmium-selenium interactions remain unclear and the final outcome of such interactions depends on the biological species investigated $[12,16,20]$.

Lepidium sativum (garden cress) is an edible vegetable from Se-accumulating Brassicaceae family. Fresh, hydroponically grown 10-14 day-old young plants are appreciated for their tangy flavor, especially in the European markets. Previous studies carried out in onion shoots revealed that the fast-growing green parts incorporate inorganic selenium (added to the 
growth medium in form of sodium selenite or selenate) and might be considered a valuable dietary source of Se-methylselenocysteine [21]. On the other hand, Lepidium sativum has often been used for assessing phytotoxicity of contaminated environments $[22,23]$. In particular, under the exposure to cadmium stress, oxidative injury has been reported [24].

The intent of this work was to acquire new experimental evidence on the protective role of selenium against cadmium toxicity in plants. Lepidium sativum (cv. Orgodowa) had been selected, due to its sensitivity to cadmium and expected feasibility for selenium incorporation. Three level factorial design was applied to obtain young plants, hydroponically grown in exposure to cadmium (cadmium chloride, $\mathrm{Cd}(\mathrm{II})$ ), selenium (sodium selenite, $\mathrm{Se}(\mathrm{IV})$ ) and their mixtures (Cd(II) + Se(IV)). Shoots growth and the concentration levels of $\mathrm{Cd}$, Se and several other metals in 2-weeks plants were quantitatively evaluated. The profile of fatty acids and the malondialdehyde concentrations were also assessed. The results obtained indicate that $\mathrm{Se}$ is capable to alleviate harmful effects imposed by $\mathrm{Cd}$, yet such protective role is apparently restricted by the concentration levels of two elements in the growth medium.

\section{Results and discussion}

The concentration levels $0,0.5,2.0 \mathrm{mg} \mathrm{L}^{-1}$ of selenium (Se(IV)) and cadmium $(\mathrm{Cd}(\mathrm{II}))$ were selected based on the results of earlier studies [20, 21, 25]. According to the experimental design applied, nine cultures were obtained, namely four exposed individually to $\mathrm{Cd}(\mathrm{II})$ or $\mathrm{Se}(\mathrm{IV})$, four exposed simultaneously to both elements and one control. In each case, growth was evaluated after seven and fourteen days of exposure and the results are presented in Figure 1. The shoots length was always lower in the presence of cadmium as compared to the controls and this effect was clearly concentration-dependent. When 0.5 $\mathrm{mg} \mathrm{L}^{-1} \mathrm{Se}$ as selenite was added alone or together with $\mathrm{Cd}(\mathrm{II})$, better growth was observed with respect to both, cadmium-exposed and control shoots. Nonetheless, the favorable impact of selenite disappeared at $2.0 \mathrm{mg} \mathrm{L}^{-1}$. These results confirm that cadmium stress causes the inhibition of garden cress growth, as reported before for this and other plant species $[12,26]$. If selenite is added at relatively low concentration, it apparently improves the growth of garden cress; however, actual amendment conditions need to be carefully selected in order to avoid selenite toxicity, also in agreement with several studies carried out on other plant types [21, 27, 28].

There exist solid experimental evidences that plants from Brassicaceae family possess the ability for selenium accumulation, however information concerning Lepidium sativum species is scarce $[29,30]$. In Table 1, the results of ICP-MS analysis are presented and it can be observed that Se content in two-week plants increased according to the increase of selenite concentration in the growth medium. Even though similar tendency can be observed in plants exposed only to $\mathrm{Cd}(\mathrm{II})$, selenium bioconcentration was always evidently higher. Thus, for concentration $0.5 \mathrm{mg} \mathrm{L}^{-1}$ and $2.0 \mathrm{mg} \mathrm{L}^{-1}$ of $\mathrm{Se}$ (IV) or Cd(II) added to the Hoagland solution, molar ratio between element (a)
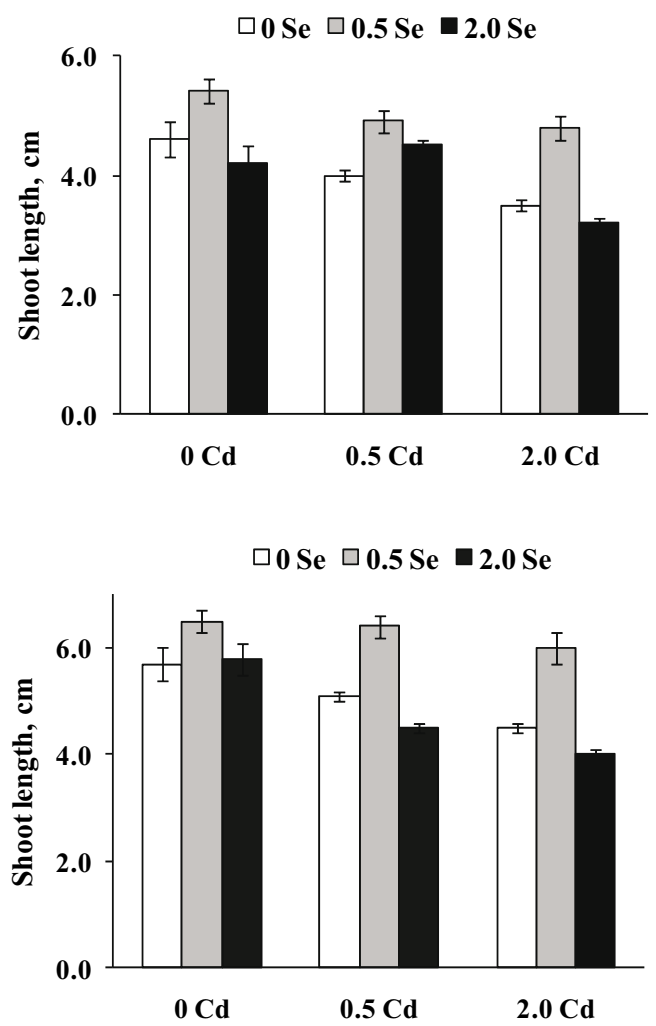

Fig. 1. Shoots length measured after seven (a) and fourteen days (b) under different exposure conditions $(\mathrm{Cd}$, Se concentration in the growth medium, $\mathrm{mg} \mathrm{L}^{-1}$ ). The bars indicate mean values for ten shoots of each culture with respective standard deviation.

in freeze-dried biomass and solution accounted for 103 and 87 for two levels of Se amendment, while for cadmium it was 40 and 32, respectively. Furthermore, in the presence of $0.5 \mathrm{mg}$ $\mathrm{L}^{-1}$ selenite, the uptake of cadmium was reduced by $48.7 \%$ and $18.8 \%$ in plants exposed to $0.5 \mathrm{mg} \mathrm{L}^{-1}$ and $2.0 \mathrm{mg} \mathrm{L}^{-1} \mathrm{Cd}(\mathrm{II})$ as compared to Cd-exposed plants grown in the absence of selenite; nonetheless, a higher concentration of $\mathrm{Se}(\mathrm{IV})(2.0$ $\mathrm{mg} \mathrm{L}^{-1}$ ) did not result in further decrease of cadmium uptake. As shown in Table 1, when two elements were added simultaneously to the growth medium the uptake of selenium also decreased. In particular, in the medium containing $0.5 \mathrm{mg} \mathrm{L}^{-1}$ $\mathrm{Se}(\mathrm{IV})$, the concentration levels $0.5 \mathrm{mg} \mathrm{L}^{-1}$ and $2.0 \mathrm{mg} \mathrm{L}^{-1}$ of $\mathrm{Cd}$ (II) caused lowering of Se content in biomass by $30.8 \%$ and $34.4 \%$ with respect to plants grown in the presence of selenite $\left(0.5 \mathrm{mg} \mathrm{L}^{-1}\right)$, while in the medium amended with $2.0 \mathrm{mg}$ $\mathrm{L}^{-1} \mathrm{Se}(\mathrm{IV})$, this decrease was $17.3 \%$ and $23.5 \%$, respectively. These results (Table 1) indicate the protective role of Se in terms of lower accessibility of cadmium to garden cress, an effect already reported for other plant species [16] and different living organisms [17, 18]. Since the lower uptake of both elements was observed, it seems plausible that the interaction between $\mathrm{Se}(\mathrm{IV})$ and $\mathrm{Cd}(\mathrm{II})$ begins in the growth medium and could be activated by exudative plant response to the stress.

The impaired status of macro- and micro mineral nutrients has often been reported in plants exposed to $\mathrm{Cd}$ (II) $[15,16$, 31]. In this work, manganese, zinc, copper, molybdenum as 
Table 1. Concentration levels of elements found in two week-old plants exposed cadmium (Cd(II)) and selenium (Se(IV)).

\begin{tabular}{|c|c|c|c|c|c|c|c|}
\hline \multicolumn{2}{|c|}{$\begin{array}{l}\mathrm{Cd}, \mathrm{Se} \text { in the growth } \\
\text { medium, } \mathrm{mg} \mathrm{L}^{-1}\end{array}$} & \multicolumn{6}{|c|}{ Metal found in the biomass, mean value $\pm \mathrm{SD}, \mu \mathrm{g} \mathrm{g}{ }^{-1}$ (dry mass), $\mathrm{n}=3$} \\
\hline $\mathrm{Cd}$ & $\mathrm{Se}$ & $\mathrm{Se}$ & $\mathrm{Cd}$ & $\mathrm{Mn}$ & $\mathrm{Zn}$ & $\mathrm{Cu}$ & Mo \\
\hline \multirow[t]{3}{*}{0} & 0 & $0.86 \pm 0.21$ & $0.81 \pm 0.01$ & $252.1 \pm 2.3$ & $228.1 \pm 1.9$ & $4.61 \pm 0.25$ & $0.65 \pm 0.02$ \\
\hline & 0.5 & $51.4 \pm 1.5$ & $0.67 \pm 0.02$ & $289.3 \pm 2.1$ & $224.2 \pm 1.6$ & $4.60 \pm 0.09$ & $0.47 \pm 0.04$ \\
\hline & 2.0 & $179 \pm 4.6$ & $0.65 \pm 0.02$ & $323.0 \pm 2.1$ & $195.5 \pm 1.1$ & $4.70 \pm 0.10$ & $0.49 \pm 0.04$ \\
\hline \multirow[t]{3}{*}{0.5} & 0 & $0.62 \pm 0.15$ & $19.9 \pm 0.74$ & $230.5 \pm 2.4$ & $205.3 \pm 1.2$ & $4.24 \pm 0.08$ & $0.48 \pm 0.03$ \\
\hline & 0.5 & $35.6 \pm 1.1$ & $10.2 \pm 0.50$ & $302.9 \pm 1.5$ & $221.0 \pm 1.5$ & $4.38 \pm 0.11$ & $0.44 \pm 0.03$ \\
\hline & 2.0 & $148 \pm 2.0$ & $11.1 \pm 0.56$ & $313.2 \pm 1.9$ & $199.0 \pm 1.8$ & $5.53 \pm 0.06$ & $0.39 \pm 0.03$ \\
\hline \multirow[t]{3}{*}{2.0} & 0 & $0.55 \pm 0.13$ & $63.8 \pm 1.36$ & $215.2 \pm 2.0$ & $194.3 \pm 1.9$ & $4.05 \pm 0.38$ & $0.44 \pm 0.02$ \\
\hline & 0.5 & $33.7 \pm 1.1$ & $51.8 \pm 1.23$ & $293.0 \pm 1.7$ & $204.4 \pm 1.9$ & $4.43 \pm 0.12$ & $0.43 \pm 0.05$ \\
\hline & 2.0 & $137 \pm 3.1$ & $49.5 \pm 1.45$ & $295.1 \pm 1.8$ & $195.1 \pm 1.4$ & $4.49 \pm 0.05$ & $0.42 \pm 0.06$ \\
\hline
\end{tabular}

essential elements present in Hoagland's solution were determined in nine cultures of garden cress and the results obtained are presented in Table 1. Under exposure to cadmium, the decrease of four elements in the biomass was observed, this effect being more marked for the higher $\mathrm{Cd}$ (II) concentration in the growth medium. In cultures exposed only to selenite, the concentration levels of zinc and molybdenum in biomass were lower compared to controls, while the uptake of manganese was clearly promoted and a tendency towards a better uptake of copper with increasing $\mathrm{Se}(\mathrm{IV})$ can also be observed. In search of more general relationships among elements under different exposure conditions, multivariate statistical analysis was carried out. Principal Component Analysis (PCA) has been used, since this method reduces the number of variables observed to a smaller set of artificial variables (called principal components) that would account for most of the variance in the raw data. As a result, partial visualization of the data structure in a reduced dimension is obtained [32]. The variables considered in this work were the concentration levels of $\mathrm{Cd}, \mathrm{Se}, \mathrm{Zn}, \mathrm{Mn}, \mathrm{Cu}$ and $\mathrm{Mo}$ found in the biomass of nine garden cress cultures. In the PCA model obtained, the first three components accounted for $92 \%$ of total data variability. In Figure $2 \mathrm{a}$, the three-dimensional plot of the sample scores is presented. In a space defined by the first three principal components, the distribution of scores was according to actual exposure conditions: from the control and cultures grown in the presence of Se(IV) (right lower corner), through cultures exposed to both elements and to those exposed only to $\mathrm{Cd}(\mathrm{II})$ (upper left corner). The three-dimensional plot of variable loadings is presented in Figure $2 \mathrm{~b}$. The variables corresponding to $\mathrm{Zn}, \mathrm{Mn}, \mathrm{Se}$ and $\mathrm{Cu}$ are grouped inversely to $\mathrm{Cd}$ variable, which confirms the adverse effect of cadmium on the uptake of essential micro elements. This distribution also indicates an antagonistic interaction between selenium and cadmium in regard to their uptake by plant. Close association of Se loading with those corresponding to $\mathrm{Cu}$ and $\mathrm{Mn}$ suggests that selenium might aid the uptake of these two important nutrients.

In order to check for possible oxidative damage due to plant exposure to $\mathrm{Cd}(\mathrm{II})$, analyses of fatty acids and malondialdehyde were carried out. In Figure $3 a$ and $3 b$, two GC-FID chromatograms obtained for control plant and plant exposed to
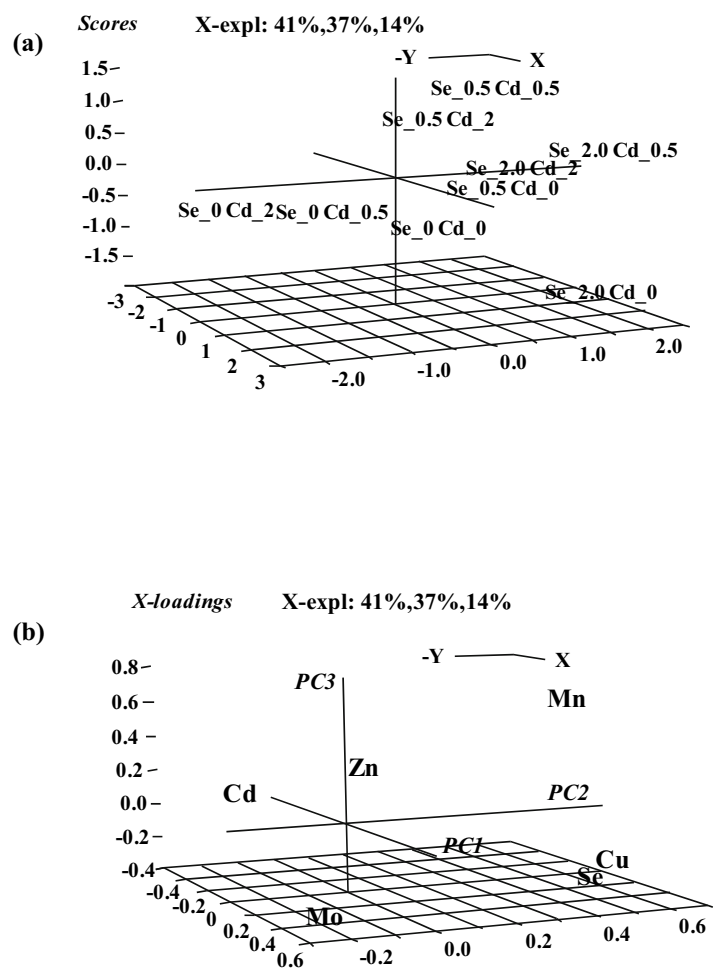

Fig. 2. Principal component analysis (PCA) of element concentration levels found in two week-old garden cress grown under different conditions of exposure: (a) three-dimensional plot of the sample scores and (b) three-dimensional plot of variable loadings in the space defined by the first three principal components.

$2 \mathrm{mg} \mathrm{L}^{-1} \mathrm{Cd}(\mathrm{II})$ are presented. Eleven compounds were identified according to their retention times, namely five saturated acids $\mathrm{C} 14, \mathrm{C} 15, \mathrm{C} 16, \mathrm{C} 18, \mathrm{C} 20$ and six unsaturated C14:1, C16:1, C18:1, C18:2, C18:3, C20:1. The increase of fatty acid saturation and the decline of $\mathrm{C} 18: 3$ can be observed in plants exposed to cadmium with respect to controls. The determination of eight major acids was accomplished in nine culture extracts and in Table 2, the molar percentage values are presented. For each culture, the molar ratio of linolenic to linoleic acid (C18:3/C18:2) was also calculated and shown in Figure 4. 

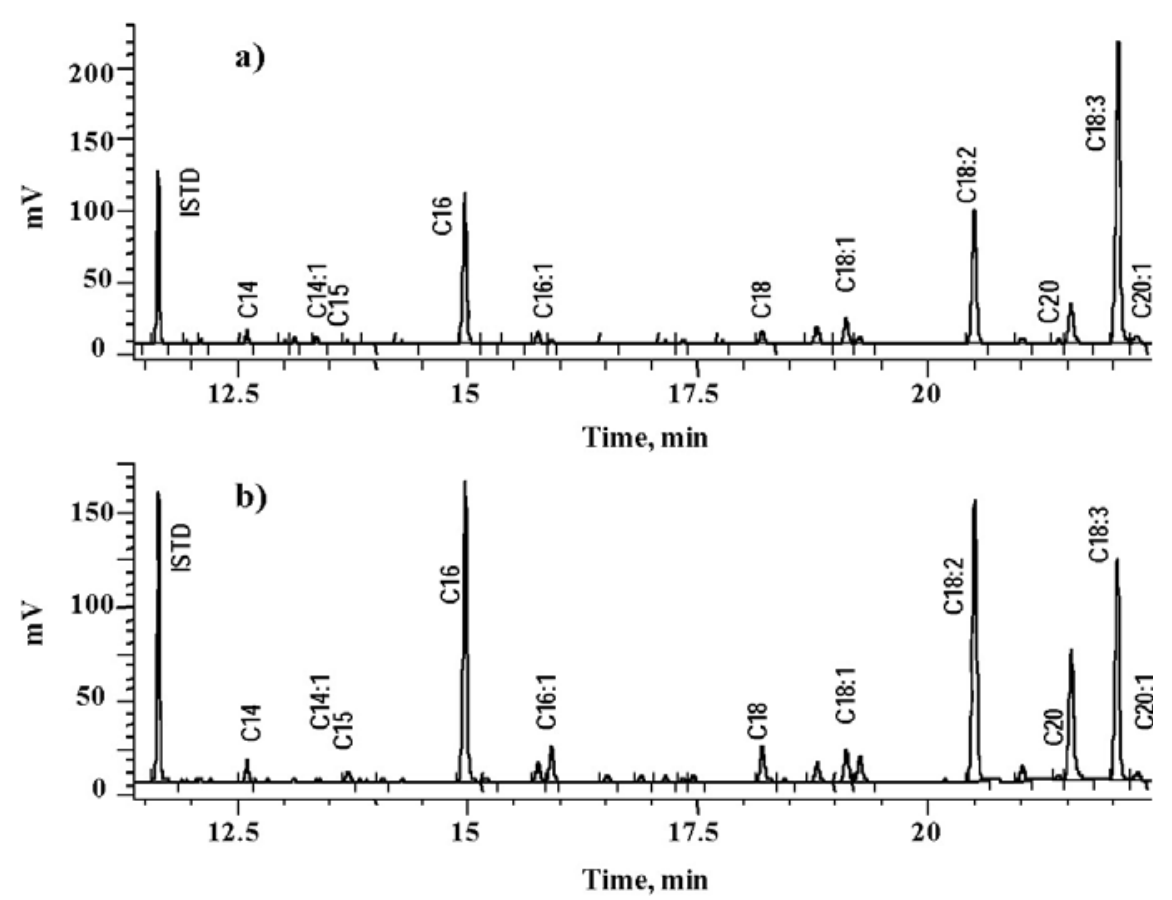

Fig. 3. GC-FID chromatograms of fatty acid methyl esters extracted from control sprouts (no Cd(II) and Se(IV) in the growth medium) (a) and sprouts exposed to $2 \mathrm{mg} \mathrm{L}^{-1} \mathrm{Cd}(\mathrm{II})$ (b).

The results obtained indicate that two-week exposure of garden cress to cadmium results in $\mathrm{Cd}(\mathrm{II})$ concentration-dependent decrease of linolenic acid, which suggests the modification of membrane fluidity [33]. The relative increase of saturated fatty acids and lower degree of fatty acid unsaturation in response to cadmium has also been reported in other plant types [12, 25, 34, 35 ] and some authors observed the protective effect of selenium against Cd-induced changes [12, 20, 36]. In this work, the sole exposure of garden cress to selenite apparently had similar effects on the fatty acid profile as exposure to cadmium: the relative amounts of $\mathrm{C} 18: 3$ and mono-unsaturated acids tended to decrease with subsequent increase of C18:2 levels when increasing concentrations of Se(IV) were added to the growth medium (Table 2, Fig. 4). Surprisingly enough, simultaneous exposure to $\mathrm{Cd}(\mathrm{II})$ and $\mathrm{Se}(\mathrm{IV})$ at any of their concentration level resulted in higher degrees of unsaturation as manifested by an increased C18:3/C18:2 ratio with respect to control and cadmium- or selenium exposed plants (Fig. 4). Thus, it appears that the presence of $\mathrm{Se}(\mathrm{IV})$ in the growth medium, at least up to $2 \mathrm{mg} \mathrm{L}^{-1}$ has adverse effect on the grade of fatty acids unsaturation in garden grass, similar to that observed under the exposure to $0.5 \mathrm{mg} \mathrm{L}^{-1} \mathrm{Cd}(\mathrm{II})$. The improvement of $\mathrm{C} 18: 3 / \mathrm{C} 18: 2$ ratio in the presence of two elements again points to the protective role of $\mathrm{Se}(\mathrm{IV})$, which might be related to a direct interaction between the two elements.

The results of malondialdehyde (MDA) determination are presented in Figure 5. As expected, exposure to cadmium resulted in $\mathrm{Cd}(\mathrm{II})$ concentration-dependent increase of this common lipid peroxidation indicator $(25.3 \%$ and $38.4 \%$ increase for two concentration levels of Cd(II) with respect to controls). For cultures grown in the presence of $0.5 \mathrm{mg} \mathrm{L}^{-1}$ and $2.0 \mathrm{mg}$
$\mathrm{L}^{-1} \mathrm{Se}(\mathrm{IV})$, MDA level observed in the control sprouts diminished by $7.5 \%$ and increased by $16.7 \%$ respectively. When the plants were exposed to the mixture of $\mathrm{Cd}$ (II) and $\mathrm{Se}$ (IV), MDA concentration was always lower than that found in cultures exposed only to $\mathrm{Cd}(\mathrm{II})$; yet this effect was much less marked when medium contained $2.0 \mathrm{mg} \mathrm{L}^{-1} \mathrm{Cd}(\mathrm{II})$ and $2.0 \mathrm{mg} \mathrm{L} \mathrm{m}^{-1}$ $\mathrm{Se}(\mathrm{IV})$. It should also be mentioned that MDA levels found in plants exposed to $2.0 \mathrm{mg} \mathrm{L}^{-1} \mathrm{Se}(\mathrm{IV}), 2.0 \mathrm{mg} \mathrm{L}^{-1} \mathrm{Se}(\mathrm{IV})+$ $0.5 \mathrm{mg} \mathrm{L}^{-1} \mathrm{Cd}(\mathrm{II}), 0.5 \mathrm{mg} \mathrm{L}^{-1} \mathrm{Se}(\mathrm{IV})+2.0 \mathrm{mg} \mathrm{L}^{-1} \mathrm{Cd}(\mathrm{II})$ and those exposed to $2.0 \mathrm{mg} \mathrm{L}^{-1} \mathrm{Se}(\mathrm{IV})+2.0 \mathrm{mg} \mathrm{L}^{-1} \mathrm{Cd}(\mathrm{II})$, were higher with respect to MDA in control plants.

Our results obtained in the analysis of fatty acids and malondialdehyde indicate that cadmium exposure causes oxidative damage in the garden cress and that selenium has a potential to alleviate such adverse effects, by lowering MDA levels and by increasing the unsaturation ratio of fatty acids. The above observations support those reported for other plant species [12, $16,20,25]$. On the other hand, selenium itself seems to exert similar phytotoxic effects as cadmium, especially when present at higher concentrations (in this work $2.0 \mathrm{mg} \mathrm{L}^{-1} \mathrm{Se}(\mathrm{IV})$ ), which has also been mentioned in other plant studies [27, 37]. The improvement of parameters related to oxidative stress under simultaneous exposure to $\mathrm{Cd}(\mathrm{II})$ and $\mathrm{Se}(\mathrm{IV})$ suggest that the protective effect of selenium would rely on the interaction between the two elements.

\section{Co4nclusions}

This work provides additional evidence on the potential effects of cadmium and selenium exposure in plants. The results 
Table 2. Fatty acids profile (\% mol) in two week-old plants exposed to cadmium (Cd(II)) and selenium (Se(IV)).

\begin{tabular}{|c|c|c|c|c|c|}
\hline \multicolumn{2}{|c|}{$\begin{array}{l}\mathrm{Cd}, \mathrm{Se} \text { in the growth medium, } \\
\mathrm{mg} \mathrm{L}^{-1}\end{array}$} & \multicolumn{4}{|c|}{ Molar percentage of individual acid $\pm \mathrm{SD}, \%(\mathrm{n}=3)$} \\
\hline $\mathrm{Cd}$ & $\mathrm{Se}$ & C16:1 & C18:1 & C18:2 & $\mathrm{C} 18: 3$ \\
\hline \multirow[t]{3}{*}{0} & 0 & $0.60 \pm 0.04$ & $3.63 \pm 0.24$ & $19.1 \pm 0.9$ & $48.3 \pm 2.3$ \\
\hline & 0.5 & $0.25 \pm 0.01$ & $2.95 \pm 0.17$ & $22.9 \pm 1.4$ & $39.9 \pm 2.4$ \\
\hline & 2.0 & $0.23 \pm 0.02$ & $2.91 \pm 0.22$ & $22.3 \pm 1.1$ & $42.9 \pm 2.1$ \\
\hline \multirow[t]{3}{*}{0.5} & 0 & $0.50 \pm 0.03$ & $3.26 \pm 0.19$ & $22.2 \pm 1.0$ & $42.5 \pm 1.8$ \\
\hline & 0.5 & $0.31 \pm 0.02$ & $7.22 \pm 0.54$ & $16.6 \pm 0.7$ & $51.8 \pm 2.0$ \\
\hline & 2.0 & $0.45 \pm 0.04$ & $3.27 \pm 0.29$ & $18.6 \pm 0.9$ & $52.4 \pm 2.4$ \\
\hline \multirow[t]{3}{*}{2.0} & 0 & $2.77 \pm 0.22$ & $2.93 \pm 0.23$ & $26.9 \pm 1.1$ & $22.4 \pm 0.9$ \\
\hline & 0.5 & $0.30 \pm 0.02$ & $3.64 \pm 0.22$ & $17.5 \pm 0.9$ & $50.2 \pm 2.6$ \\
\hline & 2.0 & $0.32 \pm 0.02$ & $2.83 \pm 0.16$ & $18.5 \pm 0.8$ & $51.4 \pm 1.0$ \\
\hline $\mathrm{Cd}$ & $\mathrm{Se}$ & $\mathrm{C} 14: 0$ & $\mathrm{C} 16: 0$ & C18:0 & C20:0 \\
\hline \multirow[t]{3}{*}{0} & 0 & $1.20 \pm 0.08$ & $17.6 \pm 0.9$ & $2.23 \pm 0.14$ & $7.42 \pm 0.76$ \\
\hline & 0.5 & $1.07 \pm 0.06$ & $22.6 \pm 1.3$ & $2.86 \pm 0.17$ & $7.41 \pm 0.84$ \\
\hline & 2.0 & $0.89 \pm 0.07$ & $20.3 \pm 1.0$ & $2.49 \pm 0.18$ & $8.03 \pm 1.01$ \\
\hline \multirow[t]{3}{*}{0.5} & 0 & $1.20 \pm 0.07$ & $18.7 \pm 0.8$ & $2.45 \pm 0.14$ & $9.25 \pm 1.23$ \\
\hline & 0.5 & $0.77 \pm 0.06$ & $14.0 \pm 0.5$ & $1.88 \pm 0.14$ & $7.35 \pm 0.71$ \\
\hline & 2.0 & $0.66 \pm 0.06$ & $16.3 \pm 0.8$ & $1.93 \pm 0.17$ & $8.56 \pm 1.20$ \\
\hline \multirow[t]{3}{*}{2.0} & 0 & $1.43 \pm 0.11$ & $23.5 \pm 0.9$ & $3.55 \pm 0.28$ & $16.4 \pm 1.9$ \\
\hline & 0.5 & $0.57 \pm 0.03$ & $14.8 \pm 0.7$ & $1.70 \pm 0.10$ & $9.10 \pm 0.85$ \\
\hline & 2.0 & $0.62 \pm 0.04$ & $16.2 \pm 0.7$ & $1.89 \pm 0.11$ & $8.24 \pm 0.78$ \\
\hline
\end{tabular}

obtained indicate that cadmium toxicity in this plant species is manifested by growth inhibition, lower status of micronutrients and increased oxidative stress. Similar, but less pronounced phytotoxic effects were observed if only Se(IV) was added to the growth medium, especially at $2 \mathrm{mg} \mathrm{L}^{-1}$ concentration level. In garden cress cultures grown under simultaneous exposure to $\mathrm{Cd}(\mathrm{II})$ and $\mathrm{Se}(\mathrm{IV})$, the adverse effect of both elements tended to disappear, and, in particular the protective effect of sele-

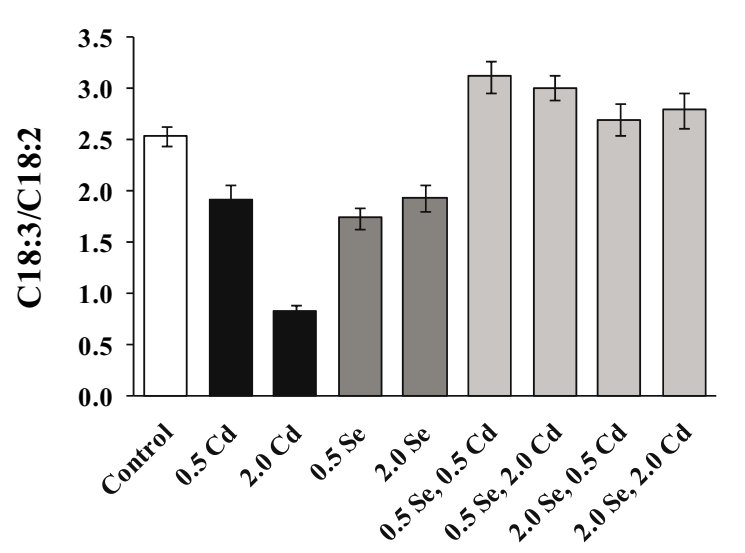

Fig. 4. Molar ratio of unsaturated acids 18:3 to 18:2 evaluated in plants under different exposure conditions. The bars indicate mean values for three independent determinations with their respective standard deviation. nium against cadmium toxicity was clearly observed. Since the growth medium amendment with $\mathrm{Se}(\mathrm{IV})$ and $\mathrm{Cd}$ (II) resulted in lower uptake of both elements with respect to the cultures exposed to individual elements and the favorable changes in the parameters measured were observed almost exclusively when both elements were present, it is concluded that the beneficial effect of selenium relies on the direct interaction between two elements both, in the growth medium and in the plant. Further

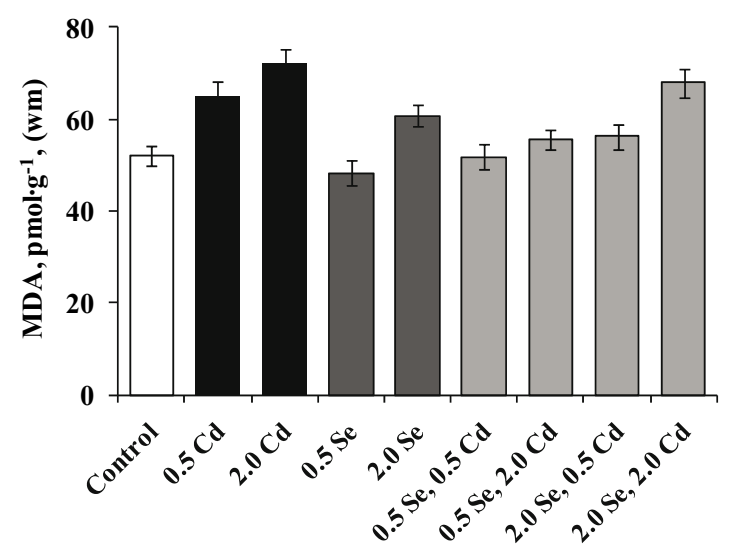

Fig. 5. Concentration levels of malondialdehyde found in plants grown in the presence of different $\mathrm{Cd}(\mathrm{II})$ and $\mathrm{Se}$ (IV) concentrations. The bars indicate mean values for three independent determinations with their respective standard deviation (wm-wet mass). 
studies are now in progress aimed at the evaluation of $\mathrm{Cd}$ and Se distribution as well as the identification and quantification of their chemical species in different plant compartments.

\section{Materials and methods}

All chemicals were of analytical reagent grade (Sigma-Aldrich). HPLC grade solvents (Fisher Scientific) and deionized water were used throughout (18.2 $\mathrm{M} \Omega \mathrm{cm}$, Labconco, USA).

\section{Plant growth}

Lepidium sativum cv. Ogrodowa seeds were purchased in the garden-specialized market in Poland. The seeds were sterilized in $70 \%$ ethanol ( $3 \mathrm{~min}$ ), then in $3.1 \%$ sodium perchlorite (15 min) and washed with sterile deionized water. The seeds were soaked in deionized water for $1 \mathrm{~h}$ and then, hydroponic germination was carried out using Hoagland's nutrient solution containing calcium nitrate $0.35 \mathrm{mM}$, calcium chloride $2.1 \mathrm{mM}$, magnesium sulfate $0.91 \mathrm{mM}$, monobasic sodium phosphate $0.97 \mathrm{mM}$, potassium nitrate $1.22 \mathrm{mM}$, boric acid $23 \mu \mathrm{M}$, manganese chloride $3.9 \mu \mathrm{M}$, molybdenum trioxide $0.5 \mu \mathrm{M}$, ferric nitrate $10 \mu \mathrm{M}$, zinc nitrate $0.6 \mu \mathrm{M}$, copper sulfate $0.5 \mu \mathrm{M}, \mathrm{pH}$ 5.8 [30]. After five days, the germinated seeds were divided in nine groups ( 250 seeds each) and further grown for two weeks at different exposure conditions. Cadmium chloride (Cd(II)), sodium selenite ( $\mathrm{Se}(\mathrm{IV})$ ) or both salts were added to the nutrient solution to obtain nine different cultures, according to the three level factorial design: $0 \mathrm{mg} \mathrm{L}^{-1}, 0.5 \mathrm{mg} \mathrm{L}^{-1}, 2.0 \mathrm{mg} \mathrm{L}^{-1} \mathrm{Cd}$ (II) and $0 \mathrm{mg} \mathrm{L}^{-1}, 0.5 \mathrm{mg} \mathrm{L}^{-1}, 2.0 \mathrm{mg} \mathrm{L}^{-1} \mathrm{Se}(\mathrm{IV})$. Young plants of each culture were harvested, washed with deionized water and ground in liquid nitrogen. For the determination of elements, a portion of the homogenized biomass was freeze-dried and another portion was freezed at $-20{ }^{\circ} \mathrm{C}$ for the analysis of fatty acids and malondialdehyde.

The germinated seeds were used to evaluate shoot growth at different exposure conditions. In these experiments, 100 seeds per each composition of the growth medium were used. Ten plants were taken at seven and fourteen days, the shoot length was measured from root/shoot boundary and mean values with their respective standard deviations were calculated.

\section{ICP-MS determination of total metal/metalloid concentrations in plants}

Three aliquots $(100 \mathrm{mg})$ of each freeze-dried sample was wet digested with concentrated nitric acid and hydrogen peroxide as described elsewhere [38]. The volume was brought to 25 $\mathrm{mL}$ with deionized water. Finally, the samples were five-fold diluted, internal standard was added (IS, In, final concentration $\left.4 \mu \mathrm{g} \mathrm{L}^{-1}\right)$.

A model 7500ce inductively coupled plasma mass spectrometer (Agilent Technologies, Tokyo, Japan) with a Meinhard nebulizer and Peltier-cooled spray chamber $\left(2{ }^{\circ} \mathrm{C}\right)$ was used. The instrument operating conditions were as follows: forward power $1500 \mathrm{~W}$, plasma gas flow rate $15 \mathrm{~L} \mathrm{~min}^{-1}$, carrier gas flow rate $0.89 \mathrm{~L} \mathrm{~min}^{-1}$, make-up gas flow rate $0.15 \mathrm{~L}$ $\mathrm{min}^{-1}$, sampling depth $10 \mathrm{~mm}$, nickel sampling and skimmer cones, dwell time $100 \mathrm{~ms}$ per isotope, collision/reaction cell gas $\mathrm{He}, 4 \mathrm{~mL} \mathrm{~min}{ }^{-1}$. The isotopes ${ }^{55} \mathrm{Mn},{ }^{63} \mathrm{Cu},{ }^{68} \mathrm{Zn},{ }^{78} \mathrm{Se},{ }^{95} \mathrm{Mo}$, ${ }^{111} \mathrm{Cd}$ were monitored $\left({ }^{115} \mathrm{In}\right.$ as IS).

External calibration was performed using multi-element standard solution $(0.1 \%$ nitric acid $(\mathrm{v} / \mathrm{v}))$ at element concentration levels: $0,0.2,0.4,1.0,2.0,5.0$ and $10 \mu \mathrm{g} \mathrm{L}^{-1}$ with addition of the internal standard $\left(4.0 \mu \mathrm{g} \mathrm{L}^{-1} \mathrm{In}\right)$. The analytical accuracy was demonstrated by analyzing two certified reference materials NIST 1643d and NIST 1572. All analyses were run in triplicate.

\section{Determination of fatty acids by gas chromatography with flame ionization detection (GC-FID)}

For the extraction of fatty acids, $300 \mathrm{mg}$ of each culture biomass was homogenized (polytron) with $4 \mathrm{~mL}$ of chloroform:methanol (2:1) and $1 \mathrm{~mL}$ of water with addition of butylhydroxytoluol as antioxidant $(10 \mu \mathrm{L}$ of $1 \%$ ethanolic BHT solution). The mixture was centrifuged (10 $000 \mathrm{~g}, 10 \mathrm{~min})$, the chloroform phase was withdrawn and the solvent was evaporated with a nitrogen stream. An aliquot $(100 \mu \mathrm{L})$ of derivatization reagent $\left(\mathrm{KOH}, 2 \% \mathrm{~m} / \mathrm{v}\right.$ and $\mathrm{NaOCH}_{3}, 0.5 \% \mathrm{~m} / \mathrm{v}$ ) and $50 \mu \mathrm{L}$ of internal standard (methyl tridecanoate, $0.2 \mathrm{mg} \mathrm{mL}^{-1}$ ) were added and FAMEs (fatty acid methyl esters) were extracted with $400 \mu \mathrm{L}$ of iso-octane. The mixture was centrifuged (10000 g, $5 \mathrm{~min})$ and the upper layer was transferred to the $\mathrm{GC}$ vials.

A Clarus 500 gas chromatograph with flame ionization detector (Perkin-Elmer, USA) was used with a HP-88 capillary column $(100 \mathrm{~m} \times 0.25 \mathrm{~mm}$, film $0.20 \mu \mathrm{m}$, Agilent Technologies, USA). The injection volume was $1 \mu \mathrm{L}$ and the instrument operating conditions were as follows: 1:10 split, inlet temperature $225^{\circ} \mathrm{C}$, hydrogen $2 \mathrm{~mL} \mathrm{~min}^{-1}$ as a carrier gas, temperature gradient: $80^{\circ} \mathrm{C} 1 \mathrm{~min}$ hold; $175^{\circ} \mathrm{C} 10 \mathrm{~min}$ ramp, 6 min hold; $210^{\circ} \mathrm{C} 5 \mathrm{~min}$ ramp, $3 \mathrm{~min}$ hold; $230^{\circ} \mathrm{C}, 26 \mathrm{~min}$ ramp, $4.5 \mathrm{~min}$ hold. The detector gases were: hydrogen $45 \mathrm{~mL} \mathrm{m^{-1 }}$ and air $450 \mathrm{~mL} \mathrm{~min}^{-1}$, the detector temperature was set at $260^{\circ} \mathrm{C}$. Fivepoint calibration was performed using 19-components FAMEs standard containing esters of C8-C22 acids (Supelco reference number 18920). The identification of fatty acids in the plant extracts was based on their retention times.

\section{Determination of malondialdehyde by reversed phase liquid chromatography (HPLC-FLD)}

Biomass $(100 \mathrm{mg}$ ) was homogenized (polytron) with $1 \mathrm{~mL}$ of trichloroacetic acid $20 \% \mathrm{~m} / \mathrm{v}$ and $10 \mu \mathrm{L}$ of $1 \% \mathrm{~m} / \mathrm{v}$ BHT solution in ethanol. The mixture was centrifuged $(10000 \mathrm{~g}, 10$ $\mathrm{min}$ ) and the derivatization of malondialdehyde was performed in $100 \mu \mathrm{L}$ of the supernatant, to which $50 \mu \mathrm{L}$ of thiobarbituric acid were added $(0.5 \% \mathrm{~m} / \mathrm{v}$ in $0.1 \mathrm{M} \mathrm{HCl})$. The reaction mixture was heated at $95{ }^{\circ} \mathrm{C}$ for $10 \mathrm{~min}$ and then centrifuged $(10,000$ 
g, $5 \mathrm{~min})$. Such prepared sample $(10 \mu \mathrm{L})$ was introduced to HPLC-FLD system.

An Agilent series 1200 liquid chromatograph equipped with an autosampler, a spectrofluorimetric detector and Chemstation (Agilent Technologies, Santa Clara, CA, USA) was used. The chromatographic column was Gemini C18 110A $(150 \times 3 \mathrm{~mm}, 5 \mu \mathrm{m})$ from Phenomenex. Gradient elution with three mobile phases (A - deionized water, $\mathrm{B}-$ ammonium phosphate monobasic $50 \mathrm{mM}, \mathrm{pH} 6, \mathrm{C}$ - methanol) was as follows: $0 \min 50 \% \mathrm{~A}, 20 \% \mathrm{~B}, 30 \% \mathrm{C} ; 0-4 \min 10 \% \mathrm{~A}, 20 \% \mathrm{~B}$, $70 \%$ C, $4-10$ min $10 \%$ A, $20 \%$ B, $70 \%$ C; $10-12 \min 50 \%$ A, $20 \%$ B, $30 \%$ C). 0 min $20 \%$ B, $10 \%$ C; $0-2 \min 40 \%$ B, $10 \%$ C; $2-14.2 \min 80 \%$ B, $10 \%$ C; $14.2-14.5 \min 20 \%$ B, $10 \%$ C. The column was kept at room temperature and the total flow rate was $0.4 \mathrm{~mL} \mathrm{~min}^{-1}$. For spectrofluorimetric detection, excitation and emission wavelengths were $515 \mathrm{~nm}$ and $553 \mathrm{~nm}$ respectively. Five point calibration was performed within the concentration range $0-1.5 \mu \mathrm{M}$ MDA.

\section{Statistical analysis}

Descriptive statistics was performed to obtain means and standard deviations. To observe possible relationships between parameters, Principal Component Analysis (PCA) were performed (Unscrambler 7.5, Camo, Norway).

\section{Acknowledgments}

The financial support from CONACYT (Mexico), project 49405 is gratefully acknowledged.

\section{References}

1. Haraguchi, H. J. Anal. At. Spectrom. 2004, 19, 5-14.

2. Haferburg, G.; Kothe, E. Appl. Microbiol. Biotechnol. 2010, 87, 1271-1280.

3. Clemens, S. Biochimie 2006, 88, 1707-1719.

4. Arruda, M. A. Z.; Azevedo, R. A. Ann. Appl. Biol. 2009, 155, 301-307.

5. Polle, A.; Schuetzenduebel, A. Topics Curr. Gen. 2004, 4, (Plant Responses to Abiotica Stress), 187-215.

6. Corrales Escobosa, A. R.; Wrobel, K.; Landero Figueroa, J. A.; Gutierrez Corona, F. J.; Wrobel, K. J. Agric. Food Chem. 2010, 58, 12392-12398.

7. Schrauzer, G. N. Crit. Rev. Biotechnol. 2009, 29, 10-17.

8. Pyrzynska, K. Food Chem. 2009, 114, 1183-1191.

9. Wrobel, K.; Wrobel, K.; Caruso, J. A., in: The determination of chemical elements in food. Applications for atomic and mass spectrometry. Caroli, S., (Ed.), John Wiley \& Sons: Hoboken, N.J., 2007; pp. 671-706.
10. Rayman, M.; Infante, H. G.; Sargent, M. British J. Nutr. 2008, 100, 238-253.

11. Pilon-Smits, E. A.; Quinn, C. F.; Tapken, W.; Malagoli, M.; Schiavon, M. Current Opin. Plant Biol. 2009, 12, 267-274.

12. Filek, M.; Keskinen, R.; Hartikainen, H.; Szarejko, I.; Janiak, A.; Miszalski, Z.; Golda, A. J. Plant Physiol. 2008, 165, 833-844.

13. Afton, S. E.; Carton, B.; Caruso, J. A. J. Exp. Botany 2009, 60, 1289-1297.

14. Peralta-Videa, J. R.; Lopez, M. L.; Narayan, M.; Saupe, J.; GardeaTorresdey, J. L. Int. J. Biochem. Cell Biol. 2009, 41, 1665-1677.

15. Hasan, S. A.; Fariduddin, q.; Ali, B.; Hayat, S.; Ahmad, A. $J$. Environ. Biol. 2009, 30, 165-174.

16. Zembala, M.; Filek, M.; Walas, S.; Mrowiec, H.; Kornas, A.; Miszalski, Z.; Hartikainen, H. Plant Soil 2010, 329, 457-468.

17. Serafin Muñoz, A. H.; Wrobel, K.; Gutierrez Corona, J. F.; Wrobel, K. Mycol. Res. 2007, 111, 626-632.

18. Caballero Arauz, I. L.; Afton, S.; Wrobel, K.; Caruso, J. A.; Gutierrez Corona, F. J.; Wrobel, K. J. Hazard. Mater. 2008, 153, 1157-1164.

19. Grant, C. A.; Buckley, W. T.; Wu, R. Can. J. Plant Sci. 2007, 87, 703-708.

20. Pedrero, Z.; Madrid, Y.; Hartikainen, H. J. Agric. Food Chem. 2008, 56, 266-271.

21. Wrobel, K.; Kannamkumarath, S. S.; Caruso, J. A.; Wysocka, I. A.; Bulska, E.; Swiatek, J.; Wierzbicka, M.; Wrobel, K. Food Chem. 2004, 86, 617-623.

22. Latif, M.; Licek, E. Environ. Toxicol. 2004, 19, 302-309.

23. Oleszczuk, P. Environ. Toxicol. 2010, 25, 38-47.

24. Czuba, M.; Kraszewski, A. Ecotoxicol. Environ. Safe. 1994, 29, 330-348.

25. Ben, A.; Wided, N.; Issam, Z.; Mokhtar, J. F. Plant Growth Regul. 2004, 53, 75-85.

26. Di Salvatore, M.; Carafa, A. M.; Carratu, G. Chemosphere 2008, 73, 1461-1464.

27. Mikkelsen, R. L.; Haghnia, G. H.; Page, A. L. J. Plant Nutr. 1987, 10, 937-950.

28. Skopikova, A.; Kralova, K.; Masarovicova, E. Ecol. Chem. Engineer. A. 2008, 15, 221-226.

29. Grant, T. D.; Montes-Bayon, M.; LeDuc, D.; Fricke, M. W.; Terry, N.; Caruso, J. A. J. Chromatogr. A 2004, 1026, 159-66.

30. Vonderheide, A. P.; Mounicou, S.; Meija, J.; Henry, H. F.; Caruso, J. A.; Shann, J. R. Analyst 2006, 131, 33-40.

31. Harikishan, U.; Kumar, A. Asian J. Water Environ. Pollut. 2010, 7, 97-101.

32. Rodriguez Flores, C.; Landero Figueroa, J. A.; Wrobel, K.; Wrobel, K. Eur. Food Res. Technol. 2009, 228, 951-958.

33. Upchurch, R. G. Biotechnol. Lett. 2008, 30, 967-977.

34. Belkhadi, A.; Hediji, H.; Abbes, Z.; Nouairi, I.; Barhoumi, Z.; Zarrouk, M.; Chaibi, W.; Djebali, W. Ecotoxicol. Environ. Safe. 2010, 73, 1004-1011.

35. Nouairi, I.; Ghnaya, T.; Ben, Y. N.; Zarrouk, M.; Ghorbel, M. H. J. Plant Physiol. 2006, 163, 1198-1202.

36. Filek, M.; Gzyl-Malcher, B.; Zembala, M.; Bednarska, M.; Laggner, P.; Kriechbaum, M. J. Plant Physiol. 2010, 167, 28-33.

37. Khattab, H. Int. J. Agr. Biol. 2004, 6, 1101-1106.

38. Landero Figueroa, J. A.; Wrobel, K.; Afton, S.; Caruso, J. A.; Gutiérrez-Corona, J. F.; Wrobel, K. Chemosphere 2008, 70, 20842091. 